\title{
The Effectiveness of Islamic Project Module Towards Formation KEMAS Kindergarten Children Values
}

\author{
Nurul Aliah Mustafa ${ }^{1}$, Mazeni Ismail ${ }^{2}$, Mohd Fauzi Kamarudin ${ }^{3} \&$ Norela Mohamed Shah ${ }^{4}$ \\ ${ }^{1}$ School of Education, Humanities \& Social Sciences, Wawasan Open University (WOU), Penang, Malaysia \\ ${ }^{2}$ Education Department, Kolej Poly-Tech MARA Kota Bharu, Kelantan, Malaysia \\ ${ }^{3}$ Centre for Language Learning, Universiti Teknikal Malaysia Melaka, Melaka, Malaysia \\ ${ }^{4}$ Faculty of Education and Liberal Studies, City University, Petaling Jaya, Selangor Darul Ehsan, Malaysia \\ Correspondence: Mohd Fauzi Kamarudin, Centre for Language Learning, Universiti Teknikal Malaysia Melaka, \\ 76100 Durian Tunggal, Melaka, Malaysia. Tel: 60-11-2681-7157. E-mail: mohdfauzi@utem.edu.my
}

Received: October 26, $2020 \quad$ Accepted: December 11, $2020 \quad$ Online Published: December 30, 2020

doi:10.5539/ass.v17n1p132 URL: https://doi.org/10.5539/ass.v17n1p132

\begin{abstract}
The aim of the present study is to evaluate the effects of using the Islamic Project $\subset$ Module by preschool teachers in the development of KEMAS kindergarten children in the state of Kelantan. This module seeks to provide significant and critical data on the integration of values in subject-matter teaching. The Modified Delphi technique was used to get consensus for the different module components. Experts from different educational fields fully involved in the module development. The respondents were 100 teachers from 100 government sponsored-kindergarten in the rural areas (TABIKA KEMAS) in Kelantan. All participating teachers were given 3 days of intensive training before implementing the Moral project approach. Using Kirkpatrick's 4-Level Assessment Model, the results of this study clearly demonstrated the effectiveness of this intervention model. Repeated measure of the ANCOVA analysis also showed that there were significant differences in comparisons between the intervention (experimental) and control groups. The findings further revealed a significant increase in teacher practice score change between the intervention and control groups over time $(\mathrm{F}$-stat $=528.71, \mathrm{p}$-value $=<0.001)$; and control over time ( $\mathrm{p}$-value $=<0.001)$. Additionally, a significant increase in teacher attitude score change between the intervention and control groups ( $\mathrm{p}$-value $=<0.001$ ) was also recorded.
\end{abstract}

Keywords: project approach, kindergarten, moral values, humanization

\section{Introduction}

The study is about the implementation of the Islamic Project $\odot$ module on children aged 5 and 6 who were edified utilizing the Pre-School Standard Curriculum across few regime-funded kindergartens in the outlying rural areas (KEMAS) of the city of Kota Bharu, Kelantan, Malaysia.

This pioneer module, specially designed as a teacher manual for Malaysian early education caregivers, was implemented by 100 KEMAS centres in the state of Kelantan. Several experts of subjects from diverse edifying fields of Islamic studies, early childhood inculcation, counselling and language provided valuable input and ingenious conceptions in the development of this module. Altogether there are five topics in the module: content, programme duration, edifying strategy, attention-prehending strategy of the target group involved in the value program and edifying staff involved, as well as strategy employed to magnetize attention of target group in utilizing the i-project. Edifiers were trained in ways to provide opportunities for children to explore and inquire, investigate, as well as articulate the things they were learning. Through these processes, it is envisaged that children would develop an acute grounding and informed conceptual understanding of the relevant moral values at hand.

Arguably, the formation of children's moral values is said to be distinctly influenced by the environment that binds and surrounds them. This is to say, the immediate environment of children, such as parents, siblings, school parties, teachers and friends, play a critical part in determining and shaping the formation of positive behaviors among children [1-6]. As a result, parents and teachers need to cooperate and collaborate to help form positive children's behavior. For example, a study conducted by [7] on 'Teacher Attitudes and Behavior toward the Inclusion of Children with Social, Emotional and Behavioral Difficulties in Mainstream Schools: An 
Application of the Theory of Planned Behavior' used 'The Theory of Planned Behavior' (TPB) to examine the relationship between teachers 'attitudes and behaviors with children's social, emotional and behavioral development. The study highlighted that courses and training workshops given to teachers were instrumental in facilitating the formation and development of good behavior, emotions and social relationships between teachers and children [8-10]. Thus, it can be inferred that educational courses and training are necessary and useful to build and boost teachers' confidence to teach and perform well in the classroom [11-13].

Teachers have crucial roles to assume towards realizing the goals of 21 st century inquiry-based learning and project-based learning pedagogy, and in doing so impact tremendous influence on the education scene in general and early childhood care and education in particular. A point worthy of note here is the aforementioned learning approaches both share a common denominator - due emphasis given to the teaching and learning processes, and not just on subject-matter content and knowledge alone. Inquiry-based learning, for instance, focuses on the importance of exploring and making self-discoveries whilst the project approach on the other hand stresses on searching for the answer. The project approach also involves in-depth investigation and exploration of children with the guide of the teacher on beneficial topics developed through authentic questions [14]. Hence the role of the teacher is to support the children through their inquiries and guide them to document and report their findings, and provide opportunities for any possible results [14-15].

All these lend support to the important role of teachers as facilitators in the learning sessions carried out in the classroom [16]. As a matter of fact, it ties in nicely with the use of Islamic Project $\odot$ module which, among other things, seeks to shine a light on the inclusion of 21 st century teaching elements in the preschool context. In this regard, the specially designed module dovetails well and resonates with one of the 5 aspirations of Education in the Malaysian Education Development Plan (PPPM) 2013-2025 [17], namely, the importance of critical thinking or project-based learning.

\section{Statement of Problem}

Reference [18], outlines several developmentally appropriate approaches for children with the project approach being one out of many. Briefly, the project approach requires children to do each activity on their own, without teacher's guidance, apart from providing opportunities for preschool children to acquire basic concepts and skills which will enable them to seamlessly move forward to primary school education later [19].

Insofar as the quality of edifying and learning in preschool edification was concerned, children's learning outcomes were quantified from a range of evaluative implements made available to preschool edifiers. These learning outcomes reflected children's academic progress. Additionally, it facilitates children's transfer of erudition and skills acquired during preschool years into their future lives that includes primary education as well as children's day-to-day life [20].

At the same time edifiers were however exhorted to take on board other edifying approaches that incline more towards children-centric acts. Essentially, the implementation of efficacious edifying and learning sessions contributed in forming the moral deportment of preschool children [21-23].

Reference [24] reiterated that written guidelines for preparing lesson plans in a project approach were not provided to teachers. Preschool teachers therefore lacked the confidence and much-needed institutional support to want to experiment with new teaching and learning methods due to inadequate reference materials or supplementary aids to enable them to execute it effectively [25].

In light of the context illustrated above, this study was carried out primarily to obtain consequential data in cognition to the utilization of moral virtues amongst preschool edifiers vis-a-vis the Islamic Project $\odot$ module. Secondly, it aimed to provide pertinent data on the aspect of assimilation of noble values in subject-matter edifying.

\subsection{Research Objective}

The main objective of this study was to evaluate the effectiveness of the use of Islamic Project $\odot$ Module by preschool teachers in the development of KEMAS Kindergarten children in the state of Kelantan, Malaysia. The data were converted into valid items for inclusion in the questionnaire which consisted the core substratum of the Islamic Project $\odot$ module [20]. The general objective was to assist in the formulation and development of a viable educational policy centrally pillared towards learning and teaching strategies pertaining to moral values development at the preschool level with the use of the Islamic Project $\odot$ Module for purpose of data collecting.

\section{Methodology}

A quantitative research design comprising experimental and control groups was used for this study. 
Questionnaire forms were distributed to teachers in one hundred KEMAS kindergarten in Kelantan. Initially 186 teachers were invited to participate in the intervention and control groups. However, some teachers could not take part in the exercise due to their tight official schedule. Hence, only 50 teachers were actively involved in the intervention group and another 50 teachers for the control set. A total of 100 questionnaires were distributed to TABIKA teachers. The data obtained were analyzed using Statistical Package for Social Sciences (SPSS) version 21. Repeated Measure ANCOVA analysis test was used in evaluating the findings of this study.

The evaluation research tool used in this study is the Kirkpatrick Assessment developed by Donald Kirkpatrick. The respondents involved in this intervention were all female teachers. Data was collected on 3 occasions: pre-test (baseline), treatment ( 2 weeks) and Post Test (3 months of intervention conducted). The descriptions related to these 3 phases were organized and tabulated according to the predetermined categories.

\section{Discussion}

The overall analysis of teacher knowledge scores showed a comparison of overall knowledge scores between both intervention groups and group, and time-based control groups. Repeated Measure ANCOVA (Repeated Measure ANCOVA) measurements were used to compare the study scores with teacher intervention group and control group on the baseline, intervention week ( 2 weeks) and 3 months according to intervention while controlling covariate. The results of the analysis are shown by combining the time-group interaction and within the group time given.

- The results of pairwise comparison with confidence interval adjustment indicated that there was a significant difference in all comparisons in the intervention group. However, in the control group, there was no significant difference in the two-time comparisons. [Baseline vs 3 months] (mean difference $=-0.20,95 \%$ CI $(-0.90,0.50)$; p-value $=>0.95)$. In conclusion, there was a significant difference in the knowledge score of teachers in each treatment group based on time.

- In terms of comparison of teachers' knowledge between two groups Timeless Treatment (Effect of Treatment), the study analysis of the comparison of teacher knowledge between two groups of treatment without time (treatment effect) proved there was a significant increase or difference in the change in teachers' knowledge score between the intervention and control groups without time (p-value $=<0.001)$.

- Group comparison (Time Effect-Treatment Interaction) demonstrated a mean comparison of teacher knowledge between two treatment group differences based on time (time effect- treatment interaction). The results of the study found there was a significant increase in the change in knowledge score between the intervention group and time-based control $(\mathrm{F}$-stat $=382.001, \mathrm{p}$-value $=<0.001)$. Within 2 weeks and 3 months, there was a difference in the mean of teacher knowledge between the control and intervention groups.

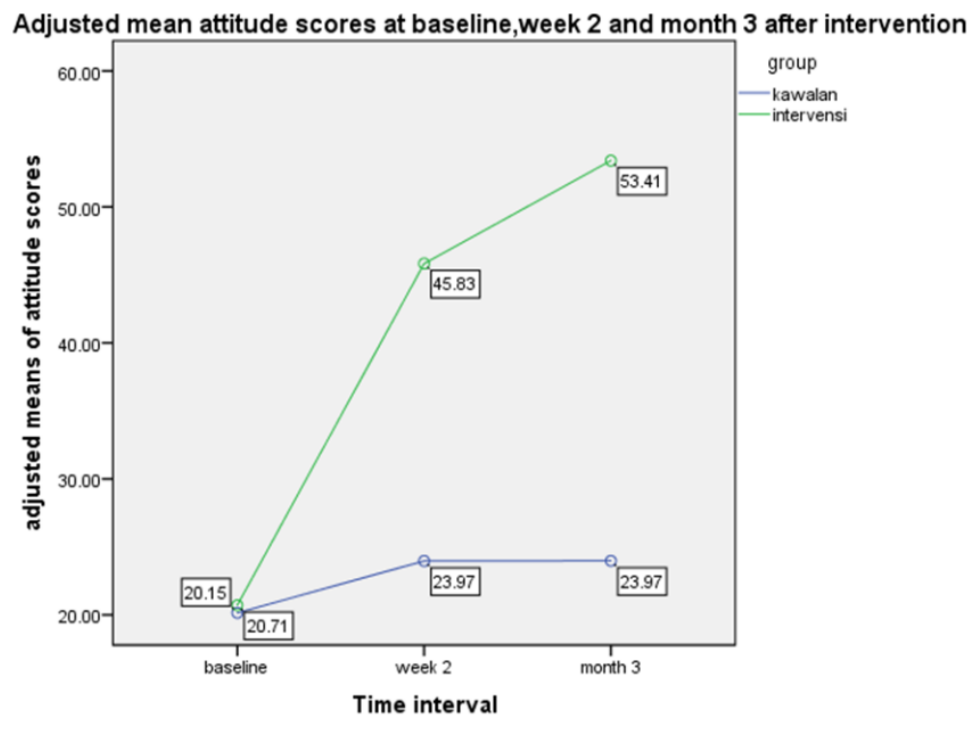

Covariates appearing in the model are evaluated at the following values: umur peserta $=29.99$

Figure 1. Plot for Adjustment Teacher Practice Score of Intervention Group and Control Group

- $\quad$ Profile plot also showed the adjusted mean (estimated marginal mean) for teacher practice for baseline time 
of weeks and over a 3 months period. The Mean practice for baseline time, 2 weeks and 3 months was seen to be different for both groups. At baseline time, 2 weeks and 3 months, mean teacher practice seemed to have increased markedly in the intervention group (Figure 1).

\section{Conclusion}

Based on the results, the study exhibited significant effectiveness of the use of Islamic Project $\odot$ module by preschool teachers in shaping morals of children from government-funded kindergartens (KEMAS) in the rural areas of Kelantan. In addition, the results showed marked improvement by way of the pre-test (Baseline), treatment ( 2 weeks after intervention) and post-test ( 3 months after intervention) measures used. During the baseline time period of about 2 weeks to 3 months, the mean value for aspects of practice, attitudes and knowledge of teachers increased significantly in the intervention group.

The Delphi procedure utilized in the analysis proved to be not only an auxiliary implement for strategy advancement in ingraining moral direction among preschool educators but withal accommodate as a multifarious medium which sanction for ingenious generation of opinions and suggestions from panel experts and specialists to address multiple themes. In adjacent, the prosperity of the Delphi process demands equitable representation from consequential stakeholders and high calibers of motivation and disposition on the component of the participants. Nevertheless, the flexibility and facilitate of administration along with conclusions drawn from the Delphi process yielded far more preponderant accommodation and benefits to those concerned. That said, this study therefore further suggest the expanded use of Islamic Project $\odot$ Module for students of other levels as well, including the possibility for use as an option or vehicle for other approaches that assist towards enhancing students 21 st century skills.

\section{References}

Ahmad, A., \& Noor, N. M. (2015). Persekitaran Keluarga dan Kesannya Terhadap Pendidikan Anak-Anak Jalanan Di Jalan Chow Kit, Kuala Lumpur. Selangor: Universiti Kebangsaan Malaysia.

Aisyah, S., \& Ag, S. (2015). Perkembangan Peserta Didik dan Bimbingan Belajar. Yogyakarta: Deepublish.

Alavi, K. et al. (2012). Kerja sosial di sekolah: Memahami dan menangani penderaan kanak-kanak (Social Work at School: Understanding and Dealing with Child Abuse). e-Bangi, 7(1), 17.

Baker-Jamieson, E. E. (2016). Empowering Parents \& Teachers: How Parents and Teachers Can Develop Collaborative Partnerships. Indiana: Xlibris Corporation.

Beneke, S., \& Ostrosky, M. M. (2009). Teachers' views of the efficacy of incorporating the project approach into classroom practice with diverse learners. Early Childhood Research and Practice, 11(1).

Buabeng-Andoh, C. (2012). Factors influencing teachers' adoption and integration of information and communication technology into teaching: A review of the literature. International Journal of Education and Development using Information and Communication Technology, 8(1), 136.

Caffaro, J. V. (2013). Sibling Abuse Trauma: Assessment and Intervention Strategies for Children, Families, and Adults. New York: Routledge. https://doi.org/10.4324/9780203797075

Carrasquillo, A. L., \& London, C. B. (2013). Parents and schools: A source book. New York: Routledge. https://doi.org/10.4324/9781315047584

Darling-Hammond, L. (2012). Powerful teacher education: Lessons from exemplary programs. New Jersey: John Wiley \& Sons.

Ellis, S., \& Gauvain, M. (2013). Social and Cultural Influences on Children's Collaborative Interactions. Children's Development within Social Context, 2(6), 155-180.

Ismail, M., Aliah, N., \& Hassan, H. (2019). Developing Islamic Module Project for Preschool Teachers Using Modified Delphi Technique. World Academy of Science, Engineering and Technology, Open Science Index 146. International Journal of Educational and Pedagogical Sciences, 13(2), 227-231.

Kamarudin, M. F., Hassan, S. N. S., Sedek, M., \& Robani, A. (2016). A Framework for Teaching Competencies in Technology and Technical Competencies: A Confirmatory Factor Analysis. The Social Sciences, 11, 2960-2964.

Katz, L. G., \& Chard, S. C. (2013). The Project Approach: An Overview. In J. Roopnarine \& J. E. Johnson (Eds.), Approaches to Early Childhood Education (6th ed., pp. 268-284). Upper Saddle River, NJ: Pearson.

Katz, L. G., Chard, S. C., \& Kogan, Y. (2014). Engaging Children's Minds: The Project Approach (3rd ed.). 
Santa Barbara, CA: Praeger.

Kementerian Pelajaran Malaysia. (2010). Kurikulum Standard Prasekolah Kebangsaan. Putrajaya: Bahagian Pembangunan Kurikulum.

Kirkpatrick, D. (1996). Great ideas revisited. Techniques for evaluating training programs. Revisiting Kirkpatrick's four-level model. Training and Development, 50, 54-59.

Kurikulum, P. (2016). Dokumen Standard Kurikulum Prasekolah. Kuala Lumpur: Kementerian Pelajaran Malaysia.

MacFarlane, K., \& Woolfson, L. M. (2013). Teacher Attitudes and Behavior toward the Inclusion of Children with Social, Emotional and Behavioral Difficulties in Mainstream Schools: An Application of the Theory of Planned Behavior. Teaching and Teacher Education, 29, 46-52. https://doi.org/10.1016/j.tate.2012.08.006

Musa, L., \& Majid, M. M. A. (2013). Pemahaman Pendidikan Islam: Kajian di Sekolah Kebangsaan Bandar Tun Razak (2), Cheras, Wilayah Persekutuan Kuala Lumpur/Understanding of Islamic Education: A Study in National School of Bandar Tun Razak (2), Cheras, Kuala Lumpur. Islamiyyat, 35(2), 5-17.

Ng, S. G., \& Abdullah, A. C. (2011). Preschool practitioners' understanding of project approach. Paper presented at the International Conference on Early Childhood and Special Education (ICECSE). Penang: Universiti Sains Malaysia.

Pelan Pembangunan Pendidikan Malaysia 2013-2025. Retrieved from http://www.moe.gov.my/userfiles/file/PPPM/Preliminary-Blueprint-BM.pdf.

Puhi, D. T. P. (2014). Peranan Guru dalam Mengembangkan Karakter Disiplin pada Anak Di Paud As-Syarief Desa Bunggalo Kecamatan Talaga Jaya Kabupaten Gorontalo (Doctoral dissertation, Universitas Negri Gorontalo).

Richards, J. C., \& Rodgers, T. S. (2014). Approaches and methods in language teaching. Cambridge University Press.

Sharp, P. (2014). Nurturing Emontional Literacy: A Practical for Teachers, Parents and Those in the Caring Professions. New Jersey: Routledge. https://doi.org/10.4324/9780203430972

Trawick-Smith, J., \& Dziurgot, T. (2011). 'Good-Fit' teacher-Child Play Interactions and The Subsequent Autonomous Play of Preschool Children. Early Childhood Research Quarterly, 26(1), 110-123. https://doi.org/10.1016/j.ecresq.2010.04.005

Weinberg, R. S., \& Gould, D. (2014). Foundations of Sport and Exercise Psychology. Human Kinetics.

\section{Copyrights}

Copyright for this article is retained by the author(s), with first publication rights granted to the journal.

This is an open-access article distributed under the terms and conditions of the Creative Commons Attribution license (http://creativecommons.org/licenses/by/4.0/). 